\title{
Pharmacology of Botulinum Toxins: From Poison to Remedy
}

\author{
Botulinum Toksinlerinin Farmakolojisi: Zehirden Çareye
}

\section{Kansu BÜYÜKAFŞAR \\ (D) 0000-0003-4117-6013}

Mersin University Medical Faculty Department of Pharmacology, Mersin, Turkey

\section{Corresponding Author Sorumlu Yazar \\ Kansu BÜYÜKAFŞAR \\ kansu23@yahoo.com}

Received / Geliş Tarihi : 10.06.2020 Accepted / Kabul Tarihi : 05.08.2020 Available Online /

Çevrimiçi Yayın Tarihi : 25.08.2020

\begin{abstract}
Botulinum toxin (BTX) is produced by autolysis of several strains of Clostridium botulinum, a gram-positive, spore-forming, rod-shaped, strictly anaerobic bacterium. However there are also non-clostridial microorganisms that are enable to produce the toxin. As some other beneficial poison, BTX also fits well the quotations by old scientists and philosophers like "Almost every substance can become a poison but only thing is the dose discriminating the difference" (Paracelsus, XVI century) or "Poisons can be employed as a means for the destruction of life or as agents for the treatment of the sick" (Claude Bernard, XIX century) or "Poison is a medicine, medicine is a poison" (Ahi Evran, XIII century). In the 1980's, Alan Scott first published articles on the use of BTX for the treatment of strabismus. The Food and Drug Administration of the USA (FDA) first approved botulinum toxin for the treatment of strabismus (crossed eye) blepharospasm (uncontrollable eye blinking) in 1989 and for glabellar rhytides in 2002, the first cosmetic indication. Since then BTX has been used for a verity of indications not only dermatological but also non-dermatological indications including onlabelled as well as off-labelled uses. In this review you will find the pharmacological profile of botulinum toxins, i.e., mode of action, pharmacokinetics, adverse effects, indications and contrindications, drug interactions, duration and site of action, etc. Furthermore, current commercial products and novel dosage forms as well as new perspective of BTX use will also be discussed.

Keywords: Botulinum toxin; pharmacology; poison; remedy; esthetic; muscle; pain.
\end{abstract}

\section{ÖZ}

Botulinum toksini (BTX) Gram (+), sporlu, çubuk șekilli ve mutlak anareobik bir bakteri olan Clostridium botulinum'un parçalanması sonucu üretilir. Ancak bu toksini üretebilen Clostridium-olmayan mikroorganizmalar da bulunmaktadır. Faydalı olabilen bazı toksinler gibi BTX de eski bilim insanları ya da filozofların "Hemen her şey zehir olabilmektedir, farkı yaratan dozdur" (Paracelsus, XVI yüzyıl) veya "Zehirler yaşamı tahrip etmek veya hastaları tedavi etmek için kullanılabilir" (Claude Bernard, XIX yüzyıl) ya da "Zehir ilaçtır, ilaç zehirdir" (Ahi Evran, XIII yüzyıl) gibi tanımlamalarına çok uymaktadır. 1980'lerde Alan Scott, şaşılık tedavisinde BTX'in kullanımı ile ilgili ilk makaleleri yayınlamıştır. Amerikan Gıda ve İlaç Dairesi (FDA), 1989'da strabismus (şaşıllk) ve blefarospazm (kontrol edilemeyen göz kırpması) tedavisi için, 2002'de de ilk kozmetik indikasyon olarak kaş-arası dikey kırışıklıklarının tedavisi için ilk kez BTX'i onaylamıştır. O günden beri BTX, sadece dermatolojik değil aynı zamanda dermatolojik-olmayan pek çok indikasyonda, hem onaylı hem de onaysız olarak kullanılmaktadır. $\mathrm{Bu}$ derlemede botulinum toksininin etki mekanizmaları, farmakokinetiği, yan etkileri, indikasyon ve kontrindikasyonları, ilaç etkileşmeleri, etki yerleri ve etki süresi vb. pek çok açıdan farmakolojik profilini bulacaksınız. Ayrıca mevcut ticari ürünleri ve yeni dozaj formları ve aynı zamanda BTX'in gelecekteki kullanımı konusu da tartıșılacaktır.

Anahtar kelimeler: Botulinum toksini; farmakoloji; zehir; çare; estetik; kas; ağrı. 


\section{INTRODUCTION}

Botulinum toxin (BTX) is produced by autolysis of a grampositive, spore-forming, rod-shaped anaerobic bacterium called as Clostridium botulinum. $(1,2)$. BTXs have been known to cause food-borne poisoning for many years. The first cases were observed in eighteenth-century Europe, and the condition was termed "sausage poisoning" or botulism as "Botulus" means sausage in Latin (3). Depending on the type of illness caused by botulinum toxins, C. botulinum strains are divided into four different groups. Bacterial groups I and II are associated with the human illness, group III is associated with illness in animals, and group IV is not related to any illness (4). In chemical sense, BTX is a protein consisting of 7 related A-G toxins (serotypes). Each serotype can also be further divided into subtypes based on differences in amino acid sequence. BTX A, B, and F are produced by group I bacteria, and toxins $\mathrm{B}, \mathrm{E}$, and $\mathrm{D}$ are produced by group II bacteria (5). Botulinum toxin types A, $\mathrm{B}$, and $\mathrm{E}$ have been identified as the most common neurotoxins causing human poisoning, whereas toxin types $\mathrm{C}$ and $\mathrm{D}$ are rarely associated with human toxicities; type $\mathrm{F}$ causes minimal human toxicity $(2,6)$.

BTXs are $\sim 150 \mathrm{kDa}$ proteins composed of two major functional chains, i.e., a light chain $(50 \mathrm{kDa})$, and a heavy chain $(100 \mathrm{KaD})$, which are connected by a disulfide bond. The heavy chain is responsible for targeting the BTX to neuronal cell membrane. Each serotype binds via different mechanisms to different target receptors $(4,7)$.

In the 1980's, Dr. Alan Scott first began publishing articles on the use of purified botulinum toxin for the treatment of strabismus (8). In 1989, the Food and Drug Administration of USA (FDA) first approved botulinum toxin for the treatment of blepharospasm. Then, in 2002, BTX received its first cosmetic indication for the treatment of dynamic rhytides of the glabella (9).

\section{BOTULINUM TOXIN PRODUCTS}

There are 4 most widely-used and commercially-available BTX products (Table 1): Botox ${ }^{\circledR}$ (OnabotulinumtoxinA, Allergan), Dysport ${ }^{\circledR}$ (AbobotulinumtoxinA, Ipsen), Xeomin ${ }^{\circledR}$ (IncobotulinumtoxinA, Merz) and Myobloc ${ }^{\circledR}$ (RimabotulinumtoxinB, Solstice Neuroscience).

All BTX-A clinical products currently available are driedpowder products that need to be reconstituted for use.
Liquid formulation with different stabilizers and components, including the omission of excipients from animal origin and HSA is considered the next generation of toxin products (10).

\section{PHARMACOLOGY OF BOTULINUM TOXIN Mechanism of Action of Botulinum Toxin}

Upon activation of nerve endings, acetylcholine-full vesicles move to the nerve membrane by the SNARE proteins (N-ethylmaleimide-sensitive factor attachment protein receptor) that modulate vesicular trafficking. These proteins are synaptobrevin, SNAP-25, and syntaxin $(7,11)$, which form a complex followed by the fusion of synaptic vesicle and terminal membrane to lead acetylcholine release into the synaptic cleft. Then acetylcholine binds to its receptors in muscles to induce muscular contraction. Botulinum toxin irreversibly inhibits acetylcholine release at neuromuscular junctions. It binds to neuronal cell membrane and is internalized by receptor-mediated endocytosis. Acidification of the endosome induces a conformational change of BTX-A structure, resulting in the translocation of the enzymatic light chain into the cytosol, which acts like a protease and cleaves SNAP-25, (synaptosomal nerve-associated protein 25 ), a presynaptic protein that takes an essential role in exocytosis of neurotransmitters. All serotypes of botulinum toxin consist of a $150-\mathrm{kDa}$, single-chain progenitor toxin, which can be triggered by a protease to produce a $100-\mathrm{kDa}$ heavy chain and a $50-\mathrm{kDa}$ light chain. When the toxin is internalized into nerve cells, the interchain disulfide bond is broken, releasing the light chain possessing endopeptidase activity. This light chain specifically cleaves one of the three SNARE proteins involved in neurotransmitter release $(2,12)$.

BTX blocks neuromuscular transmission in motor and autonomic nerve terminals by inhibiting the release of acetylcholine, resulting in a characteristic flaccid paralysis. BTX subtypes differ in cleavage SNARE complexes, e.g., BTX-A, BTX-C and BTX-E cleaves SNAP-25; however, BTX-B, BTX-D, BTX-F and BTX-G target synaptobrevin, the other important protein for exocytosis on the vesicle membrane. BTX-C also cleaves

Table 1. Some features of most widely-used commercially-available botulinum toxin preparations

\begin{tabular}{lcccc}
\hline & OnaA/BOTOX & AboA/Dysport & IncoA/Xeomin & RimaB/Myobloc \\
\hline Approval & 1989 & 1991 & 2005 & 2000 \\
Pharmaceutical forms & $\begin{array}{c}\text { Powder dissolved in } \\
\text { injectable solution }\end{array}$ & $\begin{array}{c}\text { Powder dissolved in } \\
\text { injectable solution }\end{array}$ & $\begin{array}{c}\text { Powder dissolved in } \\
\text { injectable solution }\end{array}$ & $\begin{array}{c}\text { Solution } \\
\text { Serotype }\end{array}$ \\
Size & $900 \mathrm{kDa}$ & $\mathrm{A} 1$ & $\mathrm{~A} 1$ & $\mathrm{~B}$ \\
Excipients & $\mathrm{HSA}(500 \mu \mathrm{g}), \mathrm{NaCl}$ & $\mathrm{HSA}(125 \mu \mathrm{g}), \mathrm{Lactose}$ & $\mathrm{HSA}(1 \mathrm{mg})$, Sucrose & $\mathrm{HSA}(500 \mu \mathrm{gg} / \mathrm{ml})$, \\
pH value & $\approx 7$ & $\approx 7$ & $\approx 7$ & $\mathrm{NaCl}, \mathrm{Na}-\mathrm{succinate}$ \\
Unit/vial & $50,100,200$ & 300,500 & 100,200 & 5.6 \\
Shelf life (months) & 36 & 24 & 36 & $2500,5000,10000$ \\
Toxin Quantity (ng/vial) & 5 & 4.35 & 0.6 & 24 \\
Re-constitution & $0.9 \% \mathrm{NaCl}$ & $0.9 \% \mathrm{NaCl}$ & $0.9 \% \mathrm{NaCl}$ & $25,50,100$ \\
Storage & $2-8^{\circ} \mathrm{C}$ or $<-5^{\circ} \mathrm{C}$ & $2-8^{\circ} \mathrm{C}$ & $\mathrm{Up} \mathrm{to} 25^{\circ} \mathrm{C}$ & $2-8^{\circ} \mathrm{C}$ do not freeze \\
\hline
\end{tabular}

HSA: Human Serum Albumin, modified from Fonfria et al. (10). 
syntaxin, another key protein to neurotransmitter release (Table 2, 13-18). Furthermore, a particular BTX types (i.e., BTX-C) could inactivate Rho proteins by ADPribosylation or by monoglycosylation. Hence BTX exerts diverse effects on biological system (19).

\section{Site of Action of Botulinum Toxin}

BTX mainly exerts its action on motor neurons innervating striated voluntary muscles. However, it has been demonstrated in cultured neuronal cells, that BTXs can also block the release of a wide variety of neurotransmitters but they are more potent in motor-neurons than in the other neuronal cell types (20). BTX-A also blocks ATP release from purinergic efferent nerves in the detrusor muscle. In afferent nerves, BTX-A injection markedly reduces the urothelial ATP release and increases nitric oxide (NO) release from the urothelium. Furthermore, BTX has also particular effects on smooth muscle reactivity and some other targets e.g., sensory afferents, whereby it induces an anti-nociceptive action via the inhibition of substance $\mathrm{P}$ release. Likewise, BTX can also attach to cell-surface proteins, such as Ecadherin, fibroblast growth factor receptor and vanilloid receptors. In addition to ATP, the toxin can also decrease the release of CGRP and NGF and, down-regulate TRPV1 expression. Through the inhibition of vasodilator substances such as acetylcholine, CGRP and substance-P, as well as the inhibition of muscle activity, BTX may cause the reduction of vasodilatation within the affected muscle. High dose (50 $\mathrm{U} / \mathrm{ml}$ ) of BTX-A has also been demonstrated to inhibit release of norepinephrine from sympathetic nerve endings (that's why it is effective in Raynaud syndrome) (21). Interestingly, the BTX receptors and intracellular targets are not unique for neurotransmission, as several of these receptors and targets have been found in non-neuronal cells. Affected structures by BTX are mainly:

1. The neuromuscular junction

2. Autonomic ganglia

3. Postganglionic parasympathetic nerve endings

4. Postganglionic sympathetic nerve endings that release ACh such as those in some of skeletal muscles vasculatures and eccrine sweat glands (Figure 1).

5. Non-neuronal targets

As for non-neuronal targets, BTX may also target SNAP25-expressing non-neuronal cells such as epidermal keratinocytes, adipose-derived mesenchymal stem, nasal mucosal cells, urothelial cells, epithelial cells of intestine, prostate and alveoli, neutrophils, macrophages, dermal fibroblasts, sebocytes and vascular endothelial cells $(6,15$ $17,22)$. Consequences of BTX action in these cells remain to be investigated in details.

\section{Consequences of Action of Botulinum Toxin}

Once the action of BTX prevails, the neurotransmission is blocked and the muscle may atrophy. BTX induces weakness of striated muscle. Transmission is also inhibited at neurons in muscle spindles, which may alter reflex overactivity. BTX also induces an anti-nociceptive action via the inhibition of substance P. In human skin, BTX is good for all wrinkles evoked by persistent muscular contractions. It also elicits antiaging activity on the skin by increasing skin collagen production, decreasing to slow down muscle shortening, improving skin barrier and hydration, reducing sebum production, so improves skin quality. BTX facilitate wound healing and decrease thickness of hypertrophic scars. It also decreases axillary or palmar hyperhidrosis (10). Recovery from the toxin effect can occur by sprouting of nerve endings, and formation of new synaptic clefts. Additionally, extrajunctional acetylcholine receptors have been reported to develop (6).

\section{GENERAL INDICATIONS OF BOTULINUM TOXIN}

BTXs are highly potent toxins responsible for a severe disease, called botulism. Nonetheless, these toxins are also efficient therapeutic tools with an increasing number of indications ranging from neuromuscular dysfunction to hypersecretion syndrome, pain relief, depression as well as cosmetic application. BTX was initially used for hyperactive movement disorders such as dystonia (24-26). There are several on-label uses of BTX (Table 3 ).

Table 2. Neuronal targets of BTX

\begin{tabular}{ll}
\hline BTX Type & Targets \\
\hline BTX-A & SNAP-25 \\
BTX-B & Synaptobrevin \\
BTX-C & SNAP-25 and Syntaxin \\
BTX-D & Synaptobrevin \\
BTX-E & SNAP-25 \\
BTX-F & Synaptobrevin \\
BTX-G & Synaptobrevin \\
\hline
\end{tabular}

Table 3. On-label indications of BTX

\begin{tabular}{ll}
\hline Disorders & On-Label \\
\hline Skeletal Muscles & $\begin{array}{l}\text { Cervical dystonia } \\
\text { Hemifascial spasm } \\
\text { Blepharospasm } \\
\text { Spasticity in adult and children }\end{array}$ \\
\hline \multirow{2}{*}{ Smooth Muscles } & $\begin{array}{l}\text { Detrusor overactivity } \\
\text { Neurogenic, idiopathic bladder } \\
\text { overactivity }\end{array}$ \\
\hline Exocrine Gland Hyperfunction & Sialorrhea \\
\hline Pain-Related Disorders & Chronic migraine \\
\hline \multirow{2}{*}{ Aesthetic } & $\begin{array}{l}\text { Glabellar lines } \\
\text { Lateral canthal lines }\end{array}$ \\
& Front lines \\
\hline
\end{tabular}

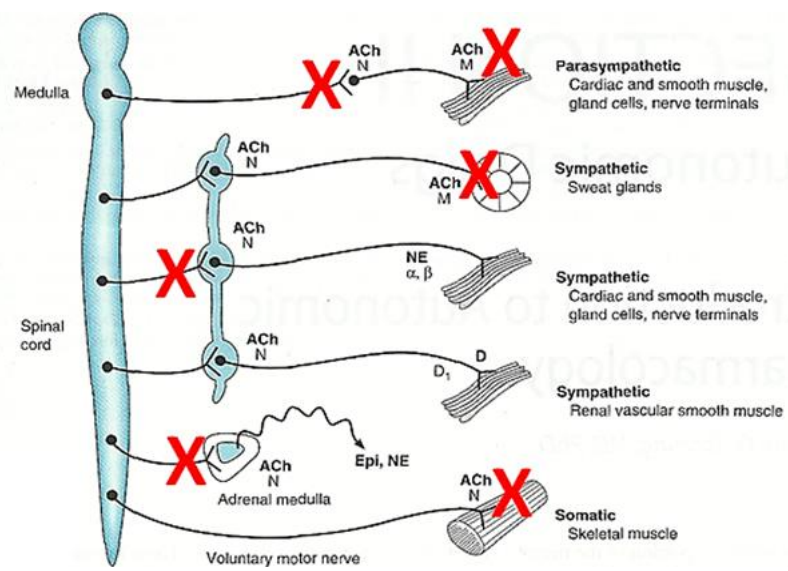

Figure 1. Site of action of botulinum toxin. BTXs act at neuromuscular junctions, autonomic ganglia, postganglionic parasympathetic nerve endings, postganglionic sympathetic nerve endings that release acetylcholine (e.g., eccrine sweat glands), modified from (23). $\mathbf{X}$ represents some of the potential inhibitory sites of BTX. 
Reports of pain reduction in patients with dystonia led to studies of its use in treatment of chronic pain states (27). The pain reduction was initially assumed to be caused by muscle relaxation and a subsequent decompression of blood vessels and sensory nerves. Later experimental studies suggested that BTX may have a central effect on the nervous system (28-31). BTX has been used in the management of spasticity in the lower limbs (32). BTX serotype A (BTX-A) is now clinically used worldwide for the treatment of chronic migraine although the mode of action remains to be fully elucidated (33). In addition, intravesical BTX injection is effective in reducing urgency and urinary incontinence by inhibiting the detrusor muscle contraction through the blockade of acetylcholine from the preganglionic and postganglionic nerves in the efferent nerves. BTX-A also blocks ATP release from purinergic efferent nerves in the detrusor muscle. In afferent nerves, BTX-A injection markedly reduces the urothelial ATP release and increases nitric oxide (NO) release from the urothelium (34).

\section{OFF-LABEL INDICATIONS OF BOTULINUM TOXIN}

BTX can also be used in a wide variety of unapproved dermatological and non-dermatological indications such as, eye brow lifting, eye widening, gummy smile, jaw sculpting, Marionette lines, mental creases, dimpling of the chin, necklines and platysmal bands, perioral lines, masseter reduction, scarring, inflammatory skin diseases, alopecia, depression, chronic migraine, genodermatoses, pruritic diseases, hyperhidrosis, palmar hyperhidrosis, axillary bromhidrosis/chromhidrosis, other disorders of sweating, stump hyperhidrosis, pompholix, periorbital syringomas, eccrine angiomatosis, eccrine naevus, eccrine hydrocystoma, pruritic dermatoses, gustatory epiphora (crocodile tears), acantholytic disorders, genodermatoses (epidermolisis bullosa simplex and pachyonychia congenital), inflammatory dermatoses, pachydermoperiostosis pachydermia, wound healing, Raynaud phenomenon, persistent facial flushing/rosacea, spasticity, stroke, traumatic brain injury, cerebral palsy, multiple sclerosis, spinal cord injury, tics, chronic low back pain, disorders of localized muscle spasm and pain, tension headache, migraine headache, cervicogenic headache, achalasia cardia, Hirschsprung disease, Oddi sphincter dysfunction, chronic anal fissure, all types of dystonia, refractory vulvodynia, vestibulodynia, vaginismus, dyspareunia, menopausal hot flashes, rosacea nasal tip, anterior neck and chest flushing (6,10,35-39).

\section{ADVERSE EFFECTS OF BOTULINUM TOXIN}

Depending on its dose, site of injection, volume and interindividual variations, there are numerous adverse effects of BTX. However, it seems to be quite safe in general when injected locally without excess dose. When it is used at excess doses it could, however, induce adverse events some of which would be serious. The following are common adverse effects of BTX: Allergic reactions, pain, edema, ecchymosis, and short-term hyperesthesia, bruising, infection (necrotizing fasciitis), delayed eyelid closure, brow ptosis, a decreased blink response, blepharoptosis, eye sensory disorders, excessive tearing and drooling, eyelid edema. In case of spreading of the toxin into the blood stream systemic side effects can be seen like generalized reactions such as nausea, malaise, flu-like symptoms and cutaneous eruptions. Headaches were the most frequent adverse events in the initial trial of BTX for the glabellar lines. Excess dose of onabotulinumtoxinA more than $400 \mathrm{U}$ in a single session can be found safe and efficacious (40) but nevertheless caution must be taken according to the patient.

Some of the side effects of BTX seem likely due to the injection technique. When used at excessive doses, BTX may be expected to produce neuromuscular weakness with a variety of severe symptoms. In such cases, the affected individual should be medically supervised for several weeks for signs and symptoms of systemic muscular weakness which could be local or distant from the site of injection. Antitoxin raised against botulinum toxin is available but it will not reverse any botulinum toxininduced effects already apparent by the time of antitoxin administration. $(41,42)$.

\section{CONTRINDICATIONS, PRECAUTIONS AND DRUG INTERACTIONS OF BOTULINUM TOXIN}

Contrindications of BTX include hypersensitivity reactions to formulation (toxin or albumin), neuromuscular disease (myasthenia gravis, Lambert-Eaton syndrome, ALS, motor neuropathies), psychological instability, pregnancy, lactating and children under 12years, existing inflammatory lesions, like acne or psoriasis at the injection site(s). Besides, the patients with unrealistic expectations, and those using too much daily facial expressions (public performers) can also be considered in the list of contrindications. Furthermore, BTX does not work for the wrinkles not caused by muscular contractions $(41,42)$. Artists such as using wind instruments (e.g., side flute and clarinet etc.) or scubadivers must be careful for the efficiency of lip contour muscles if they have been already applied by BTX to the lips-mouth area.

The use of some medications decreasing neuromuscular transmission should be avoided in patients treated with BTX. The drugs acting also on neuromuscular junction such as aminoglycoside-antibiotics, succinylcholine, curare-like neuromuscular-blockers and magnesium sulfate may increase effect of BTX. Some cholinergic medication (i.e., cholinesterase-inhibitors), penicillamine, quinine, chloroquine and hydroxychloroquine may reduce the toxin effect. Calcium channel blockers, antiplatelets and anticoagulants, NSAAI drugs (e.g., warfarin and aspirin) may cause bruising and delay in coagulation $(41,42)$. In order to avoid any bruising effects of BTX application, gingko biloba extracts, red wine, supplements of vitamin $\mathrm{E}$ and fish oil need to be stopped 2 days before the BTX application. Furthermore, on the day of BTXadministration alcohol consumption should be avoided.

\section{APPLICATION ROUTES OF BOTULINUM TOXIN}

Although BTX is given by i.m. injection there are some intradermal, transdermal, intradetrusor, transurothelial, and transepithelial delivery forms. Furthermore liquid and slow-release BTX formulations have also been developed. Topical liposomal BTX cream has also been developed for axillary hyperhidrosis. The use of BTX iontophoresis enhanced its penetration (for axillary hyperhidrosis). Transdermal delivery of BTX via jet nebulization for 
palmar, plantar, and axillary hyperhidrosis has also been tested. Topical formulation of BTX improves tolerability and adherence to therapy $(10,43)$.

\section{ACTION DURATION OF BOTULINUM TOXIN}

The onset of action of BTX-A normally begins within 1-3 days; however, some individuals may necessitate as many as 5 days. However, peak effects could be generally obtained at around 10 days. The toxin's effects last about 3-4 months. Some subtypes of BTX have different action duration, e.g., BTX-E and BTX-F have significantly shorter duration of response (3-6 weeks), which are especially required, in orthopedics and rehabilitationmedicine. Much shorter duration may also be needed for some conditions like vaginismus. However, novel formulations and delivery techniques enabling longer action duration, such as transdermal delivery or other formulations with a longer duration of response (i.e., 6-9 months) are needed for clinical interest $(6,10,44)$.

\section{PHARMACOKINETICS OF BOTULINUM TOXIN}

The effect of blood on the structure, function, and biologic half-life of the toxin was investigated but it was found that blood did not alter the structure, catalytic activity, and the neuromuscular blocking activity of the toxin. Experimental studies conducted on mice and rats have shown that the elimination half-life for native (nonmetabolized) toxin in blood and serum was around 230260 min when given with the doses that produced clinical poisoning. On the other hand binding of BTX to plasma albumin was not so high $(25-30 \%)$ and majority of the circulating toxin is free (around 70-75\%) and available for distribution to vulnerable nerve-endings. Binding of neutralizing antibodies to BTX has been demonstrated to enhance the clearance of toxin from the circulation and enhance the tissue accumulation of toxin, particularly in liver and spleen (45).

\section{SPREADING OF BOTULINUM TOXIN FROM APPLICATION SITE}

The observation that the reduction in the severity of spasticity may occur despite little neuromuscular blockade after the injection of BTX (46) and that the patients with blepharospasm or arm dystonia may experience a comfortable and sustained effect of BTX treatment in spite of the disappearance of local weakness (46-48) led the scientist implicate that the effects of BTX seems to be more than neuromuscular junction as the local action of BTX at the neuromuscular junction cannot explain whole effects of BTX (46). Accordingly, subsequent substantial evidence points out that i.m. BTX-A administration triggers alterations at the level of the central nervous system $(13,46,49-53)$. One potential explanation for these findings is an indirect plasticity of central circuits following reduction of sensory input from the injected muscles (54). Presumably, similar to tetanus neurotoxin, BTX-A may be transported along nerve axons $(53,55)$, followed by a process of cell-to-cell transfer by which the neurotoxin may gain access to second order neurons in the CNS $(46,49)$. Several pathogens exploit this trafficking route to reach the CNS (56).

On the other hand BTX can also spread to surrounding and remote muscle from the injection site. It has been demonstrated that based on compound muscle action potential (CMAP) amplitude and/or cleaved SNAP-25 immunohistochemistry in remote muscles, all botulinum toxin products may spread from the area of injection. BTX-A has a potentially greater spread to nearby and remote non-injected muscles than BTX-B in mouse and primates. BTX-CD is the most prone to spread remotely; however, BTX-D is the least. Based upon safety index, the order was obtained: BTX-F > BTX-C > BTX-D > BTX-E $>$ BTX-A > BTX-CD > BTX-B, with BTX-F being the safest. Some factors, e.g., volume, concentration, amount of toxin, formulation, serotype, needle-size, number of injections, precision of injection, biologic properties of the toxin, anatomy and tissue type of the target area, distribution of receptors, and SNARE proteins may influence spreading (Figure 2).

Interestingly, when ranked based upon safety index a different order was obtained: $\mathrm{F}>\mathrm{C}>\mathrm{D}>\mathrm{E}>\mathrm{A}>\mathrm{CD}>$ B, with BTX-F being the safest. Therefore, some effects of BTX conflict with the expected benefits, hence, require further attention. The rank order of BTX serotypes based upon spread in a study in rats was $\mathrm{CD}>\mathrm{A}>\mathrm{E}>\mathrm{C}>\mathrm{B}>$ F > D. $(10,36,37,57-59)$.
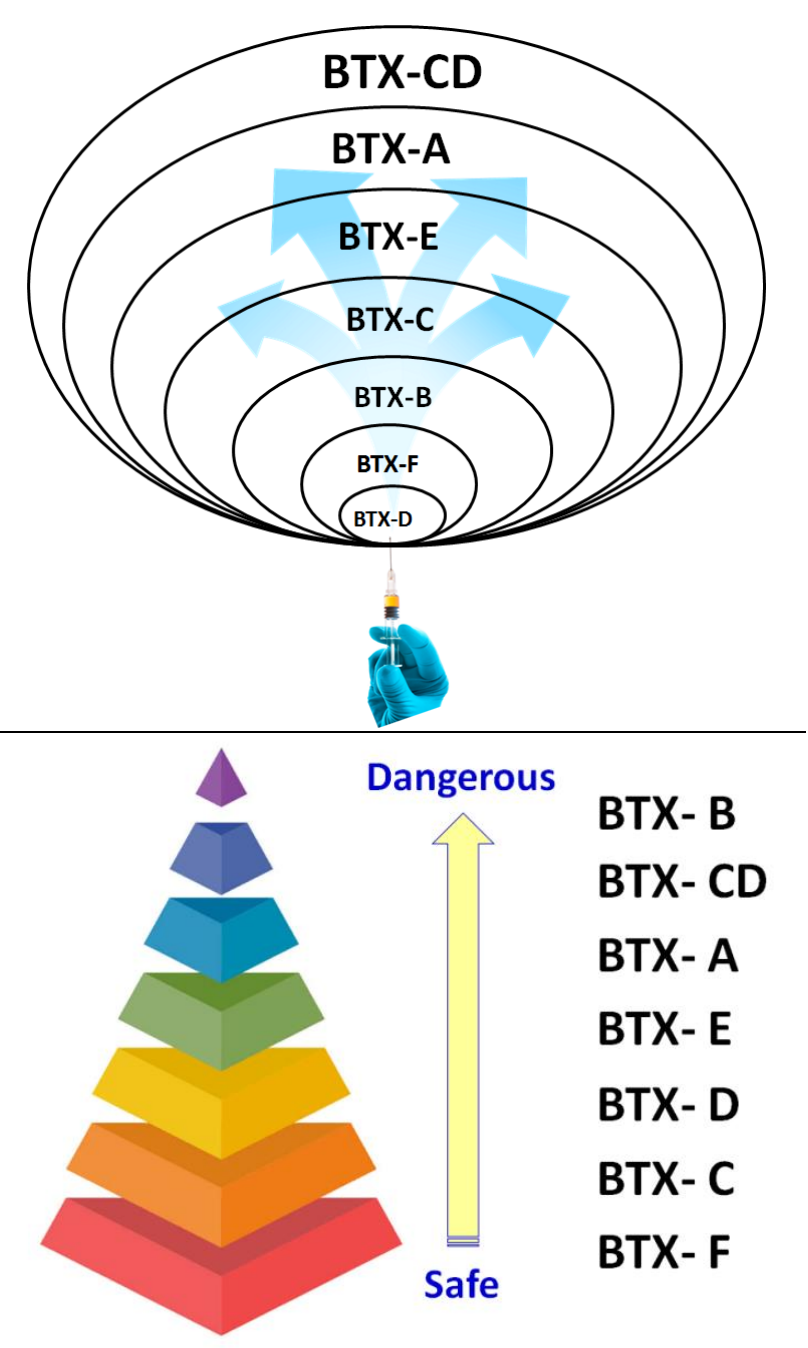

Figure 2. Spreading capacity (upper panel) and safety indexes (lower panel) of BTX. The most spreading BTX serotype is BTX-CD, the least BTX-D. As for safety, BTX$\mathrm{F}$ seems to be the safest but BTX-B the most dangerous. 


\section{NOVEL BOTULINUM TOXIN PRODUCTS}

Due to some disadvantageous features of BTX-A, more promising serotypes, e.g., biological and recombinant BTX-E products have already been developed for aesthetic and therapeutic indications. Another alternative to BTXA, is serotype BTX-C, which induces similar efficacy and duration of action without secondary resistance after chronic use. This serotype was successfully tested in a pilot series of BTX-A-non-responsive patients with focal dystonia. The other promising subtype is BTX-A2, which seems to be more potent in vitro and in vivo than BTX-A1 due to its faster penetration to neuronal cells together with higher occupancy of the cellular receptors (SV2C). In addition, BTX-A2 has a less spreading and less immunogenic feature than BTX-A1, and it seems to be less susceptible to neutralization by human antisera raised to BTX-A1. However, accumulated data showing safety grade of BTX-A2 compared to BTX-A1 is needed (10).

\section{NOVEL DELIVERY TECHNIQUES FOR BOTULINUM TOXIN}

The injection of BTX can be painful for patients and needs the specific training. Therefore, novel formulations of needlefree delivery and slow or sustained release formulations would be of clinical interest. These may include transdermal delivery or other products with a longer duration of response. FDA approved BTX cream based on ionic nanoparticle technology. There are several advantages of the cream over conventional injection such as self-application comfort, elimination of painful and traumatic needle use. Especially for conditions such as hyperhidrosis, application can require multiple uncomfortable and painful subcutaneous injections in sensitive locations, such as the palm or axilla. Due to the biological barriers limiting successful penetration of the BTX preparations to the intended tissue, transdermal formulations will be for superficial delivery. However this kind of preparation is not suitable for movement disorders that requires deeper i.m. injections. However, physical or chemical permeabilization that enables to BTX preparations to penetrate deeper layers has been developed. Accordingly, Revance Therapeutics Inc have progressed this approach for transdermal delivery of BTX-A to the clinic for both lateral canthal lines and axillary hyperhidrosis $(10,43)$.

\section{ANTIBODY DEVELOPMENT AGAINST BOTULINUM TOXIN}

One of the important issues in BTX use is antibody development against the toxin. Currently, in order to circumvent this problem several other serotypes of BTX than BTX-A or BTX-B have been explored as potential therapeutic agents in humans. BTX-E and BTX-F seem to be alternative serotypes in patients who had become resistant to BTX-A and found to be effective in dystonic patients $(44,60,61)$.

\section{CONCLUSIONS}

Since the first approval of botulinum toxin for the treatment of strabismus blepharospasm in 1989, the use of BTX has been extending towards a wide variety of indications year by year. The pleiotropic effects of this toxin are likely due to the ubiquitous distribution of its targets within the body. Once the function and importance of these targets are further elucidated we most likely to see more common use of the toxin and the market size will be expanding.

\section{REFERENCES}

1. Johnson EA, Bradshaw M. Clostridium botulinum and its neurotoxins: A metabolic and cellular perspective. Toxicon. 2001;39(11):1703-22.

2. Pirazzini M, Rossetto O, Eleopra R, Montecucco C. Botulinum neurotoxins: Biology, pharmacology, and toxicology. Pharmacol Rev. 2017;69(2):200-35.

3. Erbguth FJ. Historical notes on botulism, clostridium botulinum, botulinum toxin, and the idea of the therapeutic use of the toxin. Mov Disord. 2004;19(Suppl 8):S2-6.

4. Nawrocki EM, Bradshaw M, Johnson EA. Botulinum neurotoxin-encoding plasmids can be conjugatively transferred to diverse clostridial strains. Sci Rep. 2018;8(1):3100.

5. Lindström M, Korkeala H. Laboratory diagnostics of botulism. Clin Microbiol Rev. 2006;19(2):298-314.

6. Nigam PK, Nigam A. Botulinum toxin. Indian J Dermatol. 2010;55(1):8-14.

7. Nepal MR, Jeong TC. Alternative methods for testing botulinum toxin: Current status and future perspectives. Biomol Ther (Seolu). 2020; [Online first]. doi: https://doi.org/10.4062/biomolther.2019.200.

8. Scott AB. Botulinum toxin injection into extraocular muscles as an alternative to strabismus surgery. J Pediatr Ophthalmol Strabismus. 1980;17(1):21-5.

9. Carruthers JA, Lowe NJ, Menter MA, Gibson J, Nordquist M, Mordaunt J, et al. A multicenter, doubleblind, randomized, placebo-controlled study of the efficacy and safety of botulinum toxin type A in the treatment of glabellar lines. J Am Acad Dermatol. 2002;46(6):840-9.

10. Fonfria E, Maignel J, Lezmi S, Martin V, Splevins A, Shubber $\mathrm{S}$, et al. The expanding therapeutic utility of botulinum neurotoxins. Toxins (Basel). 2018;10(5):208.

11. Schiavo G, Matteoli M, Montecucco C. Neurotoxins affecting neuroexocytosis. Physiol Rev. 2000;80(2):717-66.

12. Humeau Y, Doussau F, Grant NJ, Poulain B. How botulinum and tetanus neurotoxins block neurotransmitter release. Biochimie. 2000;82(5):427-46.

13. Pearce LB, First ER, MacCallum RD, Gupta A. Pharmacologic characterization of botulinum toxin for basic science and medicine. Toxicon. 1997;35(9):1373-412.

14. Kim YI, Lømo T, Lupa MT, Thesleff S. Miniature endplate potentials in rat skeletal muscle poisoned with botulinum toxin. J Physiol. 1984;356(1):587-99.

15. Kumar R, Dhaliwal HP, Kukreja RV, Singh BR. The botulinum toxin as a therapeutic agent: Molecular structure and mechanism of action in motor and sensory systems. Semin Neurol. 2016,36(1):10-9.

16. Nakanishi ST, Cope TC, Rich MM, Carrasco DI, Pinter MJ. Regulation of motoneuron excitability via motor endplate acetylcholine receptor activation. J Neurosci. 2005;25(9):2226-32.

17. Whelchel DD, Brehmer TM, Brooks PM, Darragh N, Coffield JA. Molecular targets of botulinum toxin at the mammalian neuromuscular junction. Mov Disord. 2004;19(Suppl 8):S7-16.

18. Čapek P, Dickerson TJ. Sensing the deadliest toxin: technologies for botulinum neurotoxin detection. Toxins (Basel). 2010;2(1):24-53. 
19. Aktories K. Bacterial toxins that target Rho proteins. J Clin Invest. 1997;99(5): 827-9.

20. Poulain B, Lemichez E, Popoff MR. Neuronal selectivity of botulinum neurotoxins. Toxicon. 2020;178:20-32.

21. Zhou Y, Liu Y, Hao Y, Feng Y, Pan L, Liu W, et al. The mechanism of botulinum $A$ on Raynaud syndrome. Drug Des Devel Ther. 2018;12:1905-15.

22. Grando SA, Zachary CB. The non-neuronal and nonmuscular effects of botulinum toxin: an opportunity for a deadly molecule to treat disease in the skin and beyond. Br J Dermatol. 2018;178(5):1011-9.

23. Katzung BG. Autonomic drugs. In: Katzung BG, editor. Basic \& clinical pharmacology. 9th ed. New York: McGraw-Hill; 2004. p.76

24. Mauriello Jr JA. Blepharospasm, meige syndrome, and hemifacial spasm: treatment with botulinum toxin. Neurology. 1985;35(10):1499-500.

25. Shorr N, Seiff SR, Kopelman J. The use of botulinum toxin in blepharospasm. Am J Ophthalmol. 1985;99(5):542-6.

26. Jankovic J, Orman J. Botulinum A toxin for cranialcervical dystonia: a double-blind, placebo-controlled study. Neurology. 1987;37(4):616-23.

27. Binder WJ, Brin MF, Blitzer A, Schoenrock LD, Pogoda JM. Botulinum toxin type A (BOTOX) for treatment of migraine headaches: an open-label study. Otolaryngol Neck Surg. 2000;123(6):669-76.

28. Favre-Guilmard C, Auguet M, Chabrier PE. Different antinociceptive effects of botulinum toxin type $\mathrm{A}$ in inflammatory and peripheral polyneuropathic rat models. Eur J Pharmacol. 2009;617(1-3):48-53.

29. Cui M, Khanijou S, Rubino J, Aoki KR. Subcutaneous administration of botulinum toxin A reduces formalininduced pain. Pain. 2004;107(1-2):125-33.

30. Bach-Rojecky L, Lacković Z. Central origin of the antinociceptive action of botulinum toxin type A. Pharmacol Biochem Behav. 2009;94(2):234-8.

31. Bach-Rojecky L, Salković-Petrisić M, Lacković Z. Botulinum toxin type A reduces pain supersensitivity in experimental diabetic neuropathy: bilateral effect after unilateral injection. Eur $\mathrm{J}$ Pharmacol. 2010;633(1-3):10-4.

32. Love SC, Novak I, Kentish M, Desloovere K, Heinen F, Molenaers G, et al. Botulinum toxin assessment, intervention and after-care for lower limb spasticity in children with cerebral palsy: international consensus statement. Eur J Neurol. 2010;17(Suppl 2):9-37.

33. Do TP, Hvedstrup J, Schytz HW. Botulinum toxin: A review of the mode of action in migraine Acta Neurol Scand. 2018;137(5):442-51.

34. Lin YH, Chiang BJ, Liao CH. Mechanism of action of botulinum toxin $\mathrm{A}$ in treatment of functional urological disorders. Toxins (Basel). 2020;12(2):129.

35. Hehr JD, Schoenbrunner AR, Janis JE. The use of botulinum toxin in pain management: Basic science and clinical applications, plastic and reconstructive surgery. 2020;145(3):629e-36e.

36. Yucesoy CA, Ateş F. BTX-A has notable effects contradicting some treatment aims in the rat triceps surae compartment, which are not confined to the muscles injected. J Biomech. 2018;66:78-85.
37. Yucesoy CA, Emre Arıkan Ö, Ateş F. BTX-A administration to the target muscle affects forces of all muscles within an intact compartment and epimuscular myofascial force transmission. $\mathbf{J}$ Biomech Eng. 2012;134(11):111002.

38. Zakin E, Simpson D. Evidence on botulinum toxin in selected disorders. Toxicon. 2018;147:134-40.

39. Ferreira JR, Souza RP. Botulinum toxin for vaginismus treatment. Pharmacology. 2012;89(5-6):256-9.

40. Chiu SY, Patel B, Burns MR, Legacy J, Shukla AW, Ramirez-Zamora A, et al. High-dose botulinum toxin therapy: Safety, benefit, and endurance of efficacy. Tremor Other Hyperkinet Mov (NY). 2020;10. doi: http://doi.org/10.5334/tohm.527

41. Klein AW. Contraindications and complications with the use of botulinum toxin. Clin Dermatol. 2004;22(1):66-75.

42. Highlights of prescribing information of BOTOX $®$ Initial U.S. Approval: 1989;1-22.

43. Lueangarun S, Sermsilp C, Tempark T. Topical botulinum toxin type A liposomal cream for primary axillary hyperhidrosis: A double-blind, randomized, split-site, vehicle-controlled study. Dermatol Surg. 2018;44(8):1094-101.

44. Walker TJ, Dayan SH. Comparison and overview of currently available neurotoxins. J Clin Aesthet Dermatol. 2014;7(2):31-9.

45. Ravichandran E, Gong Y, Al Saleem FH, Ancharski DM, Joshi SG, Simpson LL. An initial assessment of the systemic pharmacokinetics of botulinum toxin. $\mathrm{J}$ Pharmacol Exp Ther. 2006;318(3):1343-51.

46. Mazzocchio R, Caleo M. More than at the neuromuscular synapse: Actions of botulinum neurotoxin $A$ in the central nervous system. Neuroscientist. 2015;21(1):44-61.

47. Priori A, Berardelli A, Mercuri B, Manfredi M. Physiological effects produced by botulinum toxin treatment of upper limb dystonia. Changes in reciprocal inhibition between forearm muscles. Brain. 1995;118(Pt 3):801-7.

48. Valls-Sole J, Tolosa ES, Ribera G. Neurophysiological observations on the effects of botulinum toxin treatment in patients with dystonic blepharospasm. J Neurol Neurosurg Psychiatry. 54(4):310-3.

49. Antonucci F, Di Garbo A, Novelli E, Manno I, Sartucci F, Bozzi Y, et al. Botulinum neurotoxin E (BoNT/E) reduces CA1 neuron loss and granule cell dispersion, with no effects on chronic seizures, in a mouse model of temporal lobe epilepsy. Exp Neurol. 2008;210(2):388-401.

50. Bomba-Warczak E, Vevea JD, Brittain JM, FigueroaBernier A, Tepp WH, Johnson EA, et al. Interneuronal transfer and distal action of tetanus toxin and botulinum neurotoxins A and D in central neurons. Cell Rep. 2016;16(7):1974-87.

51. Koizumi H, Goto S, Okita S, Morigaki R, Akaike N, Torii Y, et al. Spinal central effects of peripherally applied botulinum neurotoxin $\mathrm{A}$ in comparison between its subtypes A1 and A2. Front Neurol. 2014;5:98.

52. Matak I, Lacković Z. Botulinum toxin A, brain and pain. Prog Neurobiol. 2014;119-120:39-59. 
53. Restani L, Novelli E, Bottari D, Leone P, Barone I, Galli-Resta L, et al. Botulinum neurotoxin A impairs neurotransmission following retrograde transynaptic transport. Traffic. 2012;13(8):1083-9.

54. Currà $\mathrm{A}$, Trompetto $\mathrm{C}$, Abbruzzese $\mathrm{G}$, Berardelli A. Central effects of botulinum toxin type A: Evidence and supposition. Mov Disord. 2004;19(Suppl 8):S604.

55. Wiegand H, Wellhöner HH. The action of botulinum A neurotoxin on the inhibition by antidromic stimulation of the lumbar monosynaptic reflex. Naunyn Schmiedebergs Arch Pharmacol. 1977;298(3):235-8.

56. Salinas S, Schiavo G, Kremer EJ. A hitchhiker's guide to the nervous system: the complex journey of viruses and toxins. Nat Rev Microbiol. 2010;8(9):645-55.

57. Donald S, Elliott M, Gray B, Hornby F, Lewandowska A, Marlin S, et al. A comparison of biological activity of commercially available purified native botulinum neurotoxin serotypes A1 to F1 in vitro, ex vivo, and in vivo. Pharmacol Res Perspect. 2018;6(6):e00446.

58. Shaari CM, George E, Wu BL, Biller HF, Sanders I. Quantifying the spread of botulinum toxin through muscle fascia. Laryngoscope. 1991;101(9):960-4.

59. Yaraskavitch M, Leonard T, Herzog W. Botox produces functional weakness in non-injected muscles adjacent to the target muscle. J Biomech. 2008;41(4):897-902.

60. Kutschenko A, Weisemann J, Kollewe K, Fiedler T, Alvermann S, Böselt $\mathrm{S}$, et al. Botulinum neurotoxin serotype D - A potential treatment alternative for BoNT/A and B non-responding patients. Clin Neurophysiol. 2019;130(6):1066-73.

61. Lou J, Marks JD. Botulinum neurotoxins (BoNTs)antibody and vaccine. Toxins (Basel) 2018;10(12):495. 